\title{
Faculty management after higher education reforms - exploring the organizational structure of faculties considering their contextual factors
}

\author{
Ilse Hagerer \\ Chair of Business Studies/Organization and Information Systems, Osnabrueck University, \\ Germany
}

\begin{abstract}
With the implementation of the new steering model (NSM), universities should align themselves more closely with management principles. Especially, the heads of faculties must cope with higher demands of management tasks. As a result, more management positions are established and organizational structures are changed. To shed light on how structures change, we investigate the faculties of one comprehensive and one technical university within Germany - which are similar in many factors - using the contingency approach. Information about contextual factors and the number and type of established positions is gained from a systematic analysis of their homepages. Dimensions of the organizational structure are used to interpret the results. Our comparison shows that the technical university, which has established itself as an entrepreneurial university, orients its organizational structure more towards the NSM than the comprehensive university, which is reflected by more support positions in faculty management. Thus, the profile and type of the university seem to be crucial contextual factors, while our study revealed that the number of students of the faculties and the number or type of degree programs are less crucial contextual factors.
\end{abstract}

Keywords: Higher education organization; faculty management; contingency approach; organizational structure; managerial university; new steering model. 


\section{Introduction}

Universities are undergoing organizational change triggered by the new public management and the start of the Bologna Process in 1999 (Lüthje, 2010, p. 265), which aims at aligning universities toward management principles like effectiveness and efficiency. Effective organizational structures are relevant for goal attainment because they created good conditions for research and teaching and make the faculty competitive. The extent to which the new control model is implemented in the German state higher education laws varies (Lanzendorf \& Pasternack, 2009). Also, differences within a federal state can be observed although the university laws are identical within a state. This implies that there are other factors beyond university laws influencing the organizational form of the NSM. This article aims to show differences in the organizational structures of faculties from two empirical cases using a homepage analysis to identify possible contextual factors influencing the organizational structure. To achieve this goal, we transfer components of the contingency approach to higher education institutions and apply them to two selected universities: Ludwig-Maximilians-University (LMU) and Technical University of Munich (TUM).

\section{Foundation}

\subsection{The new management model}

The NSM is shaping German administrative modernization as part of the global New Public Management reform movement, which aims at increasing effectiveness and efficiency in public organizations (Brüggemeier, 2004; Christensen, 2011). Problems such as scarce state funds and higher demands on the extra-scientific benefits of research and teaching are to be solved (Lange \& Schimank, 2007). New organizational and decision-making structures aim to increase effectiveness (Pasternack, 1998). Organizational structures are defined in this work as rule systems aligning the behavior of employees with superordinate goals (Frese, 1992). The reduction of state control extends the organizational, personnel, and financial autonomy (Ziegele, 2005) and thereby strengthening university management (Krausnick, 2012). As a consequence, deans as faculty heads must cope with more complex and diverse tasks concerning administration, research, and teaching (Kehm, Merkator, \& Schneijderberg, 2010).

For this reason, new positions for deans and managers are created (Leichsenring, 2009). Scientifically qualified persons increasingly prepare management decisions and provide services (Teichler, 2005) so that new areas of responsibility have to be created, such as marketing, profile, and strategy development (Lange \& Schimank, 2007). The idea of a "largely homogeneous public administration" (Budäus, 1994) is criticized by the NSM approach. Instead, it demands situation-specific organizational forms and steering 
instruments (Brüggemeier, 2004). In each faculty, individual solutions must be found depending on size and equipment (Leichsenring, 2009).

\subsection{Contingency research}

According to contingency approaches, there are no universally effective organizational structures; instead, organizations must adapt their structures to the respective situation. Despite the discussion on whether to consider organizational size as a situational factor or organizational characteristic, it is one of the contextual factors most frequently used to explain structural differences (Blau \& Schoenherr, 1971). Several studies have found a positive correlation between size and specialization (Pugh et al., 1969). So far, mainly industrial enterprises have been analyzed using a contingency approach, whereas public organizations have only been considered occasionally (Tahar \& Boutellier, 2013; Andrews, Beynon, \& McDermott, 2016). In this work, we analyze the organizational structure and situation of faculties using a homepage analysis.

\section{Methodology: A situative view on faculties}

In the following, the organizational structure and situation of universities are analyzed. Despite higher education institutions as organizations having specific characteristics (Hüther \& Krücken, 2018) and deviate in parts from completely bureaucratic models, universities are bureaucracies (Schneijderberg, 2017). Our analysis of their organizational structure is based on dimensions referring to Max Weber's bureaucracy model (Ebers, 1992) - this view is common in the context of contingency approaches (Schulte-Zurhausen,

2014, p. 28). Table 1 explains the examined dimensions concerning their significance for faculties.

Table 1. Dimensions of the organizational structure.

\begin{tabular}{ll}
\hline Dimension & Meaning in the faculty \\
\hline Specialization & $\begin{array}{l}\text { e.g., marketing or public relation advisor, course coordination, faculty } \\
\text { manager/director }\end{array}$ \\
Formalization & $\begin{array}{l}\text { organigram, job descriptions, documented processes } \\
\text { high with a full-time dean who delegates few, low with a part-time dean in } \\
\text { addition to other deans and support positions } \\
\text { management positions with leadership function, speaker/assistant positions on } \\
\text { staff positions (Leichsenring, 2009) }\end{array}$ \\
\hline \multicolumn{1}{c}{ Source: Hagerer (2017), p. 397}
\end{tabular}

The analysis of the situation is based on the assumption that contingency factors are influencing the organizational structure (Ebers, 2004, col. 656-657). Concerning universities, size, measured in the number of degree programs and students, as well as profile, are examined as situational contextual factors at the university and faculty level. By logic deduction, the organizational structure and situation are evaluated. 


\section{Results}

The examined universities are within a German federal state to ensure comparability regarding the state higher education law. To identify the effects of particular factors, we selected universities that are as similar as possible, except in the considered factors. Table 2 illustrates the context of the universities.

Table 2. University-related contextual factors.

\begin{tabular}{lll}
\hline Contextual factor & LMU & TUM \\
\hline Profile & Tradition, equality, & Innovation, internationality, \\
internationality & entrepreneurial university \\
Type of university & Comprehensive university & Technical university \\
$\begin{array}{l}\text { Number of students } \\
\text { Number of degree }^{1}\end{array}$ & 51.918 & 42.000 \\
programs $^{2}$ & 224 & 148 \\
\hline
\end{tabular}

The higher education law prescribes number and type of deans, such as vice-deans (VD) and deans of studies (DS), which are specified in the basic regulations on the base of the course and subject structure. At both universities, it is possible to elect a dean of research (DR) (GO LMU, 2007; GO TUM, 2018). The results of the survey of faculty-related factors and deanery characteristics are presented in Tables 3 and $4 .^{3}$

\section{Interpretation and discussion of the results}

For different combinations of organizational structure dimensions and contextual factors, faculties are selected and interpreted using dimensions of the organizational structure.

\subsection{Faculties of $L M U$}

Most of the support positions are located at the faculty of physics due to a rather large number of students and study programs. There are a managing director and several employees, among others, for budget, third-party funds, personnel, and travel. These employees are not very student-oriented, but rather support the internal staff. The level of configuration and specialization is high.

\footnotetext{
${ }^{1}$ http://www.uni-muenchen.de/ueber_die_lmu/zahlen_fakten/index.html, https://www.tum.de/die-tum/die-universitaet/die-tum-inzahlen/studium, last accessed: 11/2019

2 Numbers of Bachelor's and Master's programs without teacher training: https://www.unimuenchen.de/studium/studienangebot/studiengaenge/liste_vollstaendig/index.html, https://www.tum.de/die-tum/dieuniversitaet/die-tum-in-zahlen/studium, last accessed: $12 / 2018$

${ }^{3}$ Plausibility-based group formation: With up to 1.900 students, the faculty is small, medium-sized with 1.900 to 4.000 , large with over 4.000. A small faculty has up to 8 , a medium-sized 9 to 20 , a large over 20 degree programs. A dean's office is small with up to three offices in addition to the dean, with four medium-sized, from five large. The dean's office is small with five support offices, medium with five and large with twelve.
} 
Table 3. Results of LMU.

\begin{tabular}{|c|c|c|c|c|c|c|c|c|c|}
\hline $\begin{array}{l}\text { Large } \\
\text { Medium } \\
\text { Small }\end{array}$ & $\begin{array}{l}\text { Contextua } \\
\text { factors } \\
\text { (number) }\end{array}$ & & $\begin{array}{l}\text { Dear } \\
\text { (num }\end{array}$ & $\begin{array}{l}\text { nery } \\
\text { nber) }\end{array}$ & hara & teristics & $\begin{array}{l}\text { Depar } \\
\text { charac }\end{array}$ & tment & \\
\hline 18 faculties $\mathrm{LMU}^{4}$ & Students & $\begin{array}{l}\text { Cour- } \\
\text { ses }\end{array}$ & VD & DS & DR & $\begin{array}{l}\text { Posi- } \\
\text { tions }\end{array}$ & $\begin{array}{l}\text { Num- } \\
\text { ber }\end{array}$ & $\begin{array}{l}\text { Posi- } \\
\text { tions }\end{array}$ & $\begin{array}{l}\text { Positions } \\
\text { total }\end{array}$ \\
\hline Linguistics, literature & 11.876 & 71 & 1 & 1 & 1 & 2 & 3 & 9 & 11 \\
\hline $\begin{array}{l}\text { Mathematics, } \\
\text { informatics, statistics }\end{array}$ & 5.984 & 37 & 1 & 3 & - & 1 & 3 & 9 & 10 \\
\hline Medicine & 5.850 & 7 & 1 & 3 & 1 & 14 & - & - & 14 \\
\hline Legal studies & 4.817 & 2 & 1 & 1 & - & 6 & - & - & 6 \\
\hline Social sciences & 4.502 & 15 & 1 & 1 & - & 1 & 3 & 11 & 1 \\
\hline Cultural studies & 3.833 & 28 & 1 & 2 & 1 & 5 & 2 & 4 & 9 \\
\hline $\begin{array}{l}\text { Psychology, } \\
\text { education }\end{array}$ & 3.676 & 44 & 1 & 1 & 1 & 3 & 2 & 10 & 13 \\
\hline $\begin{array}{l}\text { Business } \\
\text { administration }\end{array}$ & 3.465 & 15 & 2 & 1 & 1 & 7 & - & - & 7 \\
\hline History, art & 3.254 & 26 & 1 & 2 & - & 1 & 2 & 12 & 13 \\
\hline Physics & 2.687 & 16 & 3 & 1 & - & 20 & & & 20 \\
\hline Chemistry, pharmacy & 2.440 & 12 & 1 & 2 & - & 2 & 3 & 20 & 22 \\
\hline Geoscience & 1.856 & 13 & 1 & 2 & - & 1 & 2 & 21 & 22 \\
\hline $\begin{array}{l}\text { Philosophy, science } \\
\text { theory, religious } \\
\text { studies }\end{array}$ & 1.852 & 12 & 3 & 1 & 1 & 6 & - & - & 6 \\
\hline Biology & 1.786 & 11 & 1 & 1 & - & 5 & 2 & 10 & 15 \\
\hline Veterinary medicine & 1.607 & 1 & 1 & 1 & 1 & 2 & & & 2 \\
\hline Economics & 1.575 & 4 & 1 & 1 & 1 & 1 & 1 & 4 & 5 \\
\hline Catholic theology & 502 & 8 & 1 & 1 & 1 & 4 & 1 & 4 & 8 \\
\hline Protestant theology & 215 & 7 & 1 & 1 & 1 & 4 & - & - & 4 \\
\hline
\end{tabular}

Even having medium to large size of contextual factors, the humanities usually do not have too many positions in the sense of the NSM. Even the largest faculty of LMU, linguistics and literature, has only three dean's positions and eleven support offices, including a managing director. Due to the management position, the degree of configuration is relatively high. The faculty is subdivided into three departments, among them the there is an office manager with further employees as well as the heads of departments for budget or studies and teaching, which increases the configuration degree and counteracts centralization. These positions indicate a high degree of specialization

\footnotetext{
${ }^{4}$ Faculty-related data in table 3 and 4 are collected 2016 from the faculty homepages. Faculty related numbers of students are taken from case numbers from the student statistics (2016). Major and minor subject students are counted to ensure meaningful information about the faculty's capacity. Multiple counts are possible. Teaching study combinations were omitted in the number of degree programs, as the high number of combinations is not related to the workload.
} 
Table 4. Results of TUM.

\begin{tabular}{|c|c|c|c|c|c|c|}
\hline \multirow[b]{2}{*}{13 faculties TUM $^{4}$} & \multicolumn{2}{|c|}{$\begin{array}{l}\text { Contextual factors } \\
\text { (number) }\end{array}$} & \multicolumn{4}{|c|}{ Deanery characteristics (number) } \\
\hline & Students & Courses & VD & DS & DR & Positions total \\
\hline Weihenstephan science center & 4.776 & 29 & 2 & 6 & - & 32 \\
\hline Mechanical engineering & 4.683 & 13 & 2 & 1 & - & 29 \\
\hline School of management & 4.297 & 9 & 1 & 3 & 1 & 5 \\
\hline Informatics & 4.153 & 13 & 1 & 1 & - & 3 \\
\hline $\begin{array}{l}\text { Faculty of engineering, } \\
\text { construction, geo, environment }\end{array}$ & 3.877 & 15 & 1 & 3 & - & 4 \\
\hline $\begin{array}{l}\text { Electrical engineering and } \\
\text { information technology }\end{array}$ & 3.208 & 4 & 1 & 3 & - & 21 \\
\hline Sports and health science & 2.219 & 9 & 1 & 2 & - & 38 \\
\hline School of education & 1.944 & 23 & 1 & 2 & 1 & 28 \\
\hline Medicine & 1.784 & 2 & 2 & 1 & - & 18 \\
\hline Chemicals & 1.600 & 8 & 1 & 1 & - & 12 \\
\hline Physics & 1.402 & 5 & 1 & 1 & - & 4 \\
\hline Architecture & 1.204 & 8 & 1 & 1 & - & 13 \\
\hline Mathematics & 1.023 & 6 & - & 1 & - & 14 \\
\hline
\end{tabular}

In summary, it can be stated that LMU, as a comprehensive university, does not have many support positions. Also, the contextual factors of faculties hardly seem to influence the number of support positions. Although faculties with low sized contextual factors tend to have few support offices, even medium-sized or large faculties usually have only a rather small number of dean's positions and support positions. Faculties of natural sciences tend to have more positions. It is noticeable that more than half of the faculties have a research dean. This corresponds to the research strength.

\subsection{Faculties of TUM}

The technical profile of TUM with entrepreneurial orientation requires establishing economic contacts. The variables of Weihenstephan science center, the largest faculty of TUM, are highly pronounced concerning organizational structure and contextual factors. A matrix structure characterizes the faculty consisting of research departments and six study faculties, which support interdisciplinary cooperation. The science center has six deans of studies, two vice deans, 32 support positions, and a position for gender/diversity management. Several staff members for course coordination and counseling are assigned to each dean of studies. The degree of configuration is high. Due to the size of the faculty, many tasks are handled by a wide range of specialized staff. The study faculties should ensure flexibility by enabling the adaptation of teaching to the requirements of the working world.

The faculty of sports and health science has three dean's positions, 38 support positions, two deans of studies, and 14 employees work in the department for study and examination 
organization. The faculty has a medium size of contextual factors. Many advisory positions, among others for personnel and finances, are signs of specialization. The organization chart provided on the homepage is a sign of formalization. Together with differentiated job profiles, this indicates excellent service for students and a superior competitive position through appropriate positions. Several hierarchical levels are a sign of a high degree of configuration. The faculty is therefore very well equipped.

In summary, it is remarkable that in most cases, the faculties of the TUM do not only have many support positions in the sense of the NSM with large but even with minimal sized faculty-related contextual factors. The faculties of the LMU do not tend to have so many support offices, even in the case of large-sized faculty contextual factors; the natural science faculties tend to have more support positions. TUM commits itself to establish an entrepreneurial spirit. Profile, type of the university, and subject areas of the faculties seem to be crucial contextual factors on the organizational structure of faculties, while this applies to the number of students of the faculties and number/type of degree programs to a lesser degree.

\section{Limitations and outlook}

To enable an internal view, it is necessary to enrich the present findings with further results of expert interviews. This way, it is possible to investigate how far existing or new variables are relevant and to uncover their more profound significance for faculties. The assumption that size is a vital influencing factor on the organizational structure is only empirically confirmed to a limited extent based on only examining two universities.

\section{References}

Andrews, R., Beynon, M. J., \& McDermott, A. M. (2016). Organizational capability in the public sector: A configurational approach. Journal of Public Administration Research and Theory, 29(2), 239-258.

Blau, P. M., \& Schoenherr, R. A. (1971). The structure of organizations. New York: Basic Books.

Brüggemeier, M. (2004). Public Management. In A. Hanft (Ed.): Grundbegriffe des Hochschulmanagements (pp. 377-383). Bielefeld: Universitätsverlag Webler.

Budäus, D. (1994). Public Management: Konzepte und Verfahren zur Modernisierung öffentlicher Verwaltungen (2nd edn.). Berlin: Ed. Sigma.

Christensen, T. (2011). University governance reforms: potential problems of more autonomy? Higher Education, 62(4), 503-517.

Ebers, M. (1992). Organisationstheorie, situative. In E. Frese (Ed.): Handwörterbuch der Organisation (3rd edn., col. 1817-1838). Stuttgart: C. E. Poeschel. 
Ebers, M. (2004). Kontingenzansatz. In G. Schreyögg \& A. Werder, A. (Eds.): Handwörterbuch Unternehmensführung und Organisation (4th edn., pp. 653-667). Stuttgart: Schäffer-Poeschel.

Frese, E. (1992). Organisationsstrukturen, mehrdimensionale. In E. Frese (Ed.): Handwörterbuch der Organisation (3rd edn., col. 1670-1688). Stuttgart: C. E. Poeschel.

GO LMU. (2007). Grundordnung der Ludwig-Maximilians-Universität München vom 15. Juni 2007. Retrieved Nov. 13, 2019, from https://www.unimuenchen.de/aktuelles/amtl_voe/0100/186-grundordnung.pdf

GO TUM. (2018): Grundordnung der Technischen Universität München vom 21. August 2007 in der Fassung der Neunten Änderungssatzung vom 9. Oktober 2018. Retrieved Nov. 13, 2019, from https://portal.mytum.de/archiv/kompendium_rechtsangelegenheiten/grundordnung/2018-10-09-Englische-F-GOTUM-9-Aenderung.pdf/view

Hagerer, I. (2017). Building ideal types of faculties according to the new public management. In Proc. 7th Int. Conference The Future of Education, Florence 2017. Padova: Libreria Universitaria. 396-400.

Hüther, O., \& Krücken, G. (2018). Higher education in Germany - recent developments in an international perspective. Cham: Springer.

Kehm, B. M., Merkator, N., \& Schneijderberg, C. (2010). Hochschulprofessionelle?! Die unbekannten Wesen. Zeitschrift für Hochschulentwicklung, 5(4), 23-39.

Krausnick, D. (2012). Staat und Hochschule im Gewährleistungsstaat. Tübingen: Mohr Siebeck.

Lange, S., \& Schimank, U. (2007). Zwischen Konvergenz und Pfadabhängigkeit: New Public Management in den Hochschulsystemen fünf ausgewählter OECD-Länder. In K. Holzinger, H. Jörgens, \& C. Knill (Eds.): Transfer, Diffusion und Konvergenz von Politiken (pp. 522-548). Politische Vierteljahresschrift, Sonderheft 38. Wiesbaden: Springer.

Lanzendorf, U., \& Pasternack, P. (2009). Hochschulpolitik im Ländervergleich. In J. Bogumil \& R. G. Heinze (Eds.): Neue Steuerung von Hochschulen (pp. 13-28). Berlin: Ed. Sigma.

Leichsenring, H. (2009). Befragung zum Fakultätsmanagement 2009. Gütersloh: CHE.

Lüthje, J. (2010). Aktivierendes Wissenschaftsmanagement. In D. Simon, A. Knie, S. Hornbostel, \& K. Zimmermann (Eds.): Handbuch Wissenschaftspolitik (pp. 262-279). Wiesbaden: Springer.

Pasternack, P. (1998). Effizienz, Effektivität \& Legitimität. In HoF-Arbeitsbericht 4 (pp. 530). Institut für Hochschulforschung. Halle-Wittenberg.

Pugh, D. S. et al. (1969). The Context of Organization Structures. Administrative Science Quarterly, 14, 91-114.

Schneijderberg, C. (2017). Bureaucratization process in higher education. In J. C. Shin \& P. Teixeira (Eds.), Encyclopedia of International Higher Education Systems and Institutions (pp. 1-4). Dordrecht: Springer.

Schulte-Zurhausen, M. (2014). Organisation (6th edn.). München: Vahlen.

Tahar, S.; Boutellier, R. (2013). Resource allocation in higher education in the context of new public management. Public Management Review, 15(5), 687-711. 
Teichler, U. (2005). Einführende Überlegungen zum Thema 'Qualifizierung für eine professionelle Hochschulgestaltung: Neue Studienangebote in Deutschland'. Talk at University of Kassel 24th October.

Ziegele, F. (2005). Die Umsetzung von neuen Steuerungsmodellen (NSM) im Hochschulrecht. In R. Fisch \& S. Koch (Eds.): Neue Steuerung von Bildung und Wissenschaft (pp. 107-121). Bonn: Lemmens. 